\title{
GyrA Mutations in Nosocomial Ciprofloxacin-Resistant Escherichia coli Isolates Associated with Urinary Tract Infections
}

\author{
Rasha H. El-Mahdy ${ }^{1}$, Mohammed A. Saleh ${ }^{2 *}$ and Aalaa Aboelnour ${ }^{3}$ \\ ${ }^{1}$ Department of Medical Microbiology and Immunology, Faculty of Medicine, \\ Mansoura University, Egypt \\ ${ }^{2}$ Department of Medical Microbiology and Immunology, Faculty of Medicine, \\ Al-Azhar University, New Damietta, Egypt \\ ${ }^{3}$ Department of Clinical Pathology, Faculty of Medicine, Mansoura University, Egypt \\ *Corresponding author
}

\section{A B S T R A C T}

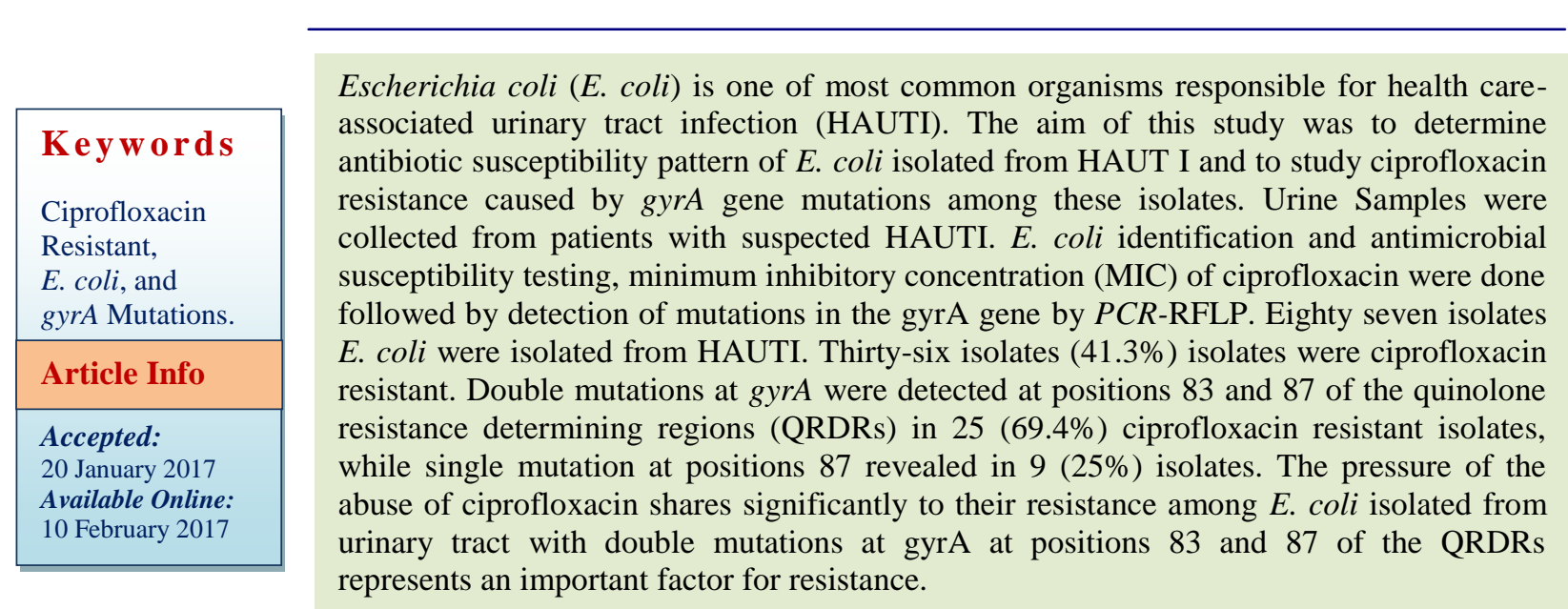

\section{Introduction}

Urinary tract infections (UTIs) are the fourth health care-associated infection (Magill et al., 2014). E. coli is a major pathogen in healthcare-associated urinary tract infection (HAUTI) (Cullen et al., 2012).Antimicrobial resistance in E. coli causing UTIs is rising in several countries (Niranjan and Malini, 2014), (Karlowsky et al., 2002).

In recent decades, fluoroquinolones have been broadly used to treat health care-associated Gram-negative bacterial infections.
Ciprofloxacin is the most commonly used fluoroquinolone for treatment of UTIs as it exists in oral and intravenous preparations (Schaeffer, 2002). However, resistance to fluoroquinolones has become prevalent due to this widespread use (Ena et al.,1998). Mutation in DNA gyrase and DNA topoisomerase IV are the most important mechanisms of resistance to fluoroquinolones (Minarini and Darini, 2012; Moon et al., 2010).Other resistance mechanisms, including, alteration in the outer membrane 
proteins, efflux pump, target mutation and drug enzymatic modification are found (Cavaco et al., 2008). The aim of this study was to assess antibiotic susceptibility pattern of $E$. coli isolated from HAUTI, in addition, determine ciprofloxacin resistance and the role of mutations in the gyrA gene in ciprofloxacin-resistance.

\section{Materials and Methods}

Urine samples (mid-stream, catheter aspirated) were collected from January to August 2016 from the patients suspected to have UTIs in Mansoura University Hospitals referred to Microbiology Department in Faculty of Medicine, Mansoura University. They were processed by the semi-quantitative culture technique on the cystine lactose electrolyte deficient (CLED). Colonies identified by colonial morphology, Gramstained films and conventional biochemical tests including, oxidase test, Kligler- iron agar test, IMVC tests ( Mahon et al., 2000).

\section{Antimicrobial susceptibility testing}

Antibiotic susceptibility testing was done by disc diffusion method according to the Clinical Laboratory Standards Institute (CLSI) guidelines (Wayne, 2007). The group of intermediate susceptibility was considered together with the resistant strains. Minimum inhibitory concentration was done for ciprofloxacin using E-test strips (bioMérieux Inc., MO, USA) following the manufacturer's instructions.

\section{Detection of GyrA mutations}

Genomic DNA extraction from the isolates was done through a boiling technique. PCR was performed and primers and thermocycling conditions used were designed as described previously by Ozeki et al., (1997). gyrA PCR product is about $164 \mathrm{bp}$.
Point mutation at positions Ser-83 and Asp87 of gyrA was tested by restriction fragmet length polymorphism (RFLP) analysis of PCR products. The PCR products were digested with HinfI (Ferment as, Thermo Fisher Scientific Inc) to detect mutations at positions Ser-83 and Asp- 87 (Ozeki et al., 1997). Digestion products according to mutation site are listed in table 1. Products were determined by electrophoresis in 3\% (w/v) agarose gel then visualized under UV light using $50 \mathrm{bp}$ ladder as DNA size marker

\section{Results and Discussion}

During the study period, a total of $87 \mathrm{E}$. coli isolates were collected from patients with HAUTIs. Sixty women (79 \%) and 27 men (31\%), mean age was 49years+13.79 (range, 21 to 70 years) with 46samples $(52.8 \%)$ were collected from patients in intensive care units (ICUs).

The highest rates of resistance were found for cefotaxime(78.2\%), aztreonam (65.5\%), sulphametoxazole-trimethoprim (65.5\%). Thirty-six isolates $(41.3 \%)$ were ciprofloxacin resistant. Antibiotic resistance pattern of $E$. coli among ciprofloxacin resistant and ciprofloxacin sensitive are summarized in table 2 .

Ciprofloxacin resistance in E. coli was significantly higher in old age, prior urinary catheterization and prior quinolone use (Table $3)$.

No mutation was detected in ciprofloxacin sensitive isolates. Most of ciprofloxacin resistant isolates $34(94.4 \%)$ had mutation in gyrA with 25 isolates (73.5\%) had mutations at both Ser-83 and Asp-87, while9 (26.5\%) had a single mutation at Asp-87. No single mutation at Ser-83 was detected. MIC of cirprofloxacin in gyrA mutations are listed in table 4. Treatment of UTIs becomes more 
difficult because of emergence of antibioticresistant bacteria (Arslan et al., 2005). In this study, high rate of antibiotics resistance was found in E. coli. Similarly, high rate of resistance was previously reported in several studies (Niranjan and Malini, 2014), (Jadhav et al., 2011), (Khorvash et al., 2009). On other hand, lower resistance rate was observed by Sotto et al., (2001). This variation in resistance may be due to difference in local antibiotic prescription policy (Sotto et al., 2001).

The most common antibiotics used in treatment of UTIs are trimethoprimsulfamethoxazole, quinolones, cephalosporins and semisynthetic penicillins with or without beta-lactamase inhibitors (Arslan et al., 2005).

Table.1 HinfIPCR-RFLP patterns of gyrA

\begin{tabular}{|l|c|}
\hline Mutation site & Restriction fragment length \\
\hline Mutations at both Ser-83 and Asp-87 & $164 \mathrm{bp}$ \\
\hline No mutations at either Ser-83 or Asp-87 & $109 \mathrm{bp}$ and $40 \mathrm{bp}$ \\
\hline Single mutation at Ser-83 & $124 \mathrm{bp}$ and $40 \mathrm{bp}$ \\
\hline Single mutation at Asp-87 & $109 \mathrm{bp}$ and 55 bp \\
\hline
\end{tabular}

Table.2 Antibiotic resistance profiles of ciprofloxacin resistant and ciprofloxacin sensitive E. coli isolates

\begin{tabular}{|l|c|c|c|c|}
\hline Antibiotics & $\begin{array}{c}\text { Ciprofloxacin } \\
\text { resistant (36) }\end{array}$ & $\begin{array}{c}\text { Ciprofloxacin } \\
\text { sensitive (51) }\end{array}$ & $\begin{array}{c}\text { Total } \\
\text { Resistance } \\
\text { No. (\%) }\end{array}$ & P value \\
\hline $\begin{array}{l}\text { Amoxicillin- } \\
\text { clavulanic acid }\end{array}$ & 19 & 36 & $55(63.2)$ & .09 \\
\hline Cefotaxime & 31 & 37 & $68(78.2)$ & .13 \\
\hline Gentamicin & 18 & 30 & $48(55.2)$ & .41 \\
\hline Imipenem & 14 & 13 & $27(31)$ & .18 \\
\hline Amikacin & 11 & 21 & $32(36.8)$ & .31 \\
\hline Nitrofurantoin & 15 & 20 & $35(40.2)$ & .81 \\
\hline $\begin{array}{l}\text { Sulphamethoxazole- } \\
\text { Trimethoprim }\end{array}$ & 29 & 28 & $57(65.5)$ & $.013 *$ \\
\hline Aztreonam & 21 & 36 & $57(65.5)$ & .23 \\
\hline Tazocin & 20 & 18 & $38(43.7)$ & .06 \\
\hline
\end{tabular}

Table.3 Risk factors for ciprofloxacin resistance among urinary E. coli

\begin{tabular}{|l|c|c|c|l|}
\hline Risk factors & $\begin{array}{c}\text { Ciprofloxacin } \\
\text { resistant }\end{array}$ & $\begin{array}{c}\text { ciprofloxacin } \\
\text { sensitive }\end{array}$ & $\begin{array}{c}\text { P } \\
\text { value }\end{array}$ & $\begin{array}{c}\text { Odds Ratio } \\
\text { (Confidence Interval) }\end{array}$ \\
\hline Age > 60 years & 16 & 10 & $.01^{*}$ & $.30(.117-.791)$ \\
\hline Urinary catheter & 26 & 25 & $.03^{*}$ & $2.7(1.08-6.7)$ \\
\hline ICU & 22 & 24 & .19 & $1.7(.7-4.2)$ \\
\hline $\begin{array}{l}\text { Prior ciprofloxacin } \\
\text { use (6 months) }\end{array}$ & 16 & 12 & $.04^{*}$ & $2.6(1.03-6.5)$ \\
\hline
\end{tabular}


Table.4 MIC of Ciprofloxacin and gyrA gene mutations in ciprofloxacin resistant E. coli

\begin{tabular}{|c|c|c|c|c|c|c|c|}
\hline \multirow[t]{2}{*}{ gyrA } & \multirow{2}{*}{$\begin{array}{c}\text { Total } \\
\text { Number } \\
(36)\end{array}$} & \multicolumn{6}{|c|}{$\begin{array}{l}\text { No. of } E \text {. coli isolates corresponding } \\
\text { Ciprofloxacin MIC }(\mu \mathrm{g} / \mathrm{ml})\end{array}$} \\
\hline & & 4 & 8 & 16 & 32 & 64 & $>64$ \\
\hline Wild type & $2(5.5 \%)$ & 2 & 0 & 0 & 0 & 0 & 0 \\
\hline $\begin{array}{l}\text { Ser83 and } \\
\text { Asp87 }\end{array}$ & $25(69.4 \%)$ & 0 & 1 & 15 & 1 & 5 & 3 \\
\hline Asp87 & $9(25.1 \%)$ & 6 & 3 & 0 & 0 & 0 & 0 \\
\hline
\end{tabular}

In this study, high resistance was reported to cefotaxime, trimethoprim and lower resistance for imipenem and nitrofurantoin. In Consistent with our results, high trimethoprim resistance and low nitrofurantoin resistance was also observed in previous reports (Bean et al., 2008; Cullen et al., 2012; Schito et al., 2009).

At first, the incidence of fluoroquinolone resistance was very low (Kresken and Wiedemann, 1988). In the last decade, widespread use of fluoroquinolones has leaded to increase resistance among urinary $E$. coli (Fasugba et al., 2015). In this study, it was found that ciprofloxacin resistance rate was $41.3 \%$ and this is in consistent with previous study of Tandogdu et al., (2014) in which Ciprofloxacin resistance among urinary E. coli in different geographic areas varies from $35-57 \%$. On other contrary, lower prevalence $5.3 \%$ was reported by other researcher (Sotto et al., 2001). In our work, ciprofloxacin resistance isolates were significantly associated with sulphamethoxazole-trimethoprim resistance. Previous works observed concomitant trimethoprim and ciprofloxacin resistance in urinary E. coli (Karlowsky et al., 2002), (Zhanel et al., 2000). Prior quinolone use, old age and prior urinary catheterization were significantly associated with ciprofloxacin resistance. The same factors were previously recognized (Sotto et al., 2001). Moreover, Ena et al., (1998) showed increase in fluoroquinolone resistance in urinary $E$ coli from 3 to $20 \%$ that associated with usage of ciprofloxacin. Mutation in gyrA is the most frequent mechanism of fluoroquinolone resistance in clinical isolates (Ruiz, 2003). The majority of ciprofloxacin resistant isolates in this study showed double mutations ingyra. The same was previously reported by several publications (Minarini and Darini, 2012; Moon et al., 2010; Chenia et al., 2006). Intermediate to high-level resistance was associated with these strains with double mutations comparable with previous studies who stated that low-level fluoroquinolone resistance in $E$. coli is related to a single mutation in the gyrA whereas high-level resistance associated with multiple mutations (Chenia et al., 2006; Minarini and Darini, 2012)

From the previous results, it was concluded that the uncontrolled use of certain antibiotics such as quinolones that should be reserved for resistant isolates strongly lead to increase the frequency of their resistance. Moreover, double mutations ingyrA represents a significant mechanism in resistance to ciprofloxacin.

\section{References}

Arslan, H., Azap, O. K., Ergonul, O., and Timurkaynak, F. (2005). Risk factors for ciprofloxacin resistance among Escherichia coli strains isolated from community-acquired urinary tract infections in Turkey. $J$ Antimicrob 
Chemother, 56(5), 914-918. doi: 10.1093/jac/dki344

Bean, D. C., Krahe, D., and Wareham, D. W. (2008). Antimicrobial resistance in community and nosocomial Escherichia coli urinary tract isolates, London 20052006. Ann Clin Microbiol Antimicrob, 7, 13. doi: 10.1186/1476-0711-7-13

Cavaco, L. M., Frimodt-Moller, N., Hasman, H., Guardabassi, L., Nielsen, L., and Aarestrup, F. M. (2008). Prevalence of quinolone resistance mechanisms and associations to minimum inhibitory concentrations in quinolone-resistant Escherichia coli isolated from humans and swine in Denmark. Microb Drug Resist, 14(2), 163-169. doi: 10.1089/mdr.2008.0821

Chenia, H. Y., Pillay, B., and Pillay, D. (2006). Analysis of the mechanisms of fluoroquinolone resistance in urinary tract pathogens. $J$ Antimicrob Chemother, 58(6), 1274-1278. doi: 10.1093/jac/dkl404

Connie, R Mahon, Mahon, D, Lehman, C, and Manuselis, G. (2000). Textbook of diagnostic microbiology. WB Saunder, $U K$.

Cullen, I. M., Manecksha, R. P., McCullagh, E., Ahmad, S., O'Kelly, F., Flynn, R. J., Thornhill, J. A. (2012). The changing pattern of antimicrobial resistance within 42,033 Escherichia coli isolates from nosocomial, community and urology patient-specific urinary tract infections, Dublin, 1999-2009. BJU Int, 109(8), 1198-1206. doi: 10.1111/j.1464410X.2011.10528.X

Ena, J., Lopez-Perezagua, M. M., MartinezPeinado, C., Cia-Barrio, M. A., and RuizLopez, I. (1998). Emergence of ciprofloxacin resistance in Escherichia coli isolates after widespread use of fluoroquinolones. Diagn Microbiol Infect Dis, 30(2), 103-107.

Fasugba, O., Gardner, A., Mitchell, B. G., and Mnatzaganian, G. (2015). Ciprofloxacin resistance in community- and hospitalacquired Escherichia coli urinary tract infections: a systematic review and metaanalysis of observational studies. BMC Infect Dis, 15, 545. doi: 10.1186/s12879015-1282-4

Jadhav, S., Hussain, A., Devi, S., Kumar, A., Parveen, S., Gandham, N.,... Ahmed, N. (2011). Virulence characteristics and genetic affinities of multiple drug resistant uropathogenic Escherichia coli from a semi urban locality in India. PLoS One, 6(3), e18063. doi: 10.1371/journal.pone.0018063

Karlowsky, J. A., Kelly, L. J., Thornsberry, C., Jones, M. E., and Sahm, D. F. (2002). Trends in antimicrobial resistance among urinary tract infection isolates of Escherichia coli from female outpatients in the United States. Antimicrob Agents Chemother, 46(8), 2540-2545.

Khorvash, F., Mostafavizadeh, K., Mobasherizadeh, S., and Behjati, M. (2009). Susceptibility pattern of E. coliassociated urinary tract infection (UTI): a comparison of spinal cord injury-related and nosocomial UTI. Med Sci Monit, 15(11), Cr579-582.

Kresken, M., and Wiedemann, B. (1988). Development of resistance to nalidixic acid and the fluoroquinolones after the introduction of norfloxacin and ofloxacin. Antimicrob Agents Chemother, 32(8), 1285-1288.

Magill, S. S., Edwards, J. R., Bamberg, W., Beldavs, Z. G., Dumyati, G., Kainer, M. A., Fridkin, S. K. (2014). Multistate point-prevalence survey of health careassociated infections. $N$ Engl $\mathrm{J} \mathrm{Med}$, 370(13), 1198-1208. doi: 10.1056/NEJMoa1306801

Minarini, L. A., and Darini, A. L. (2012). Mutations in the quinolone resistancedetermining regions of gyrA and parC in Enterobacteriaceae isolates from Brazil. Braz J Microbiol, 43(4), 1309-1314. doi: 10.1590/s1517-838220120004000010

Moon, D. C., Seol, S. Y., Gurung, M., Jin, J. S., Choi, C. H., Kim, J., Lee, J. C. (2010). Emergence of a new mutation and its accumulation in the topoisomerase IV 
gene confers high levels of resistance to fluoroquinolones in Escherichia coli isolates. Int J Antimicrob Agents, 35(1), 76-79.

doi: 10.1016/j.ijantimicag.2009.08.003

Niranjan, V., and Malini, A. (2014). Antimicrobial resistance pattern in Escherichia coli causing urinary tract infection among inpatients. Indian $\mathrm{J} \mathrm{Med}$ Res, 139(6), 945-948.

Ozeki, S., Deguchi, T., Yasuda, M., Nakano, M., Kawamura, T., Nishino, Y., and Kawada, Y. (1997). Development of a rapid assay for detecting gyrA mutations in Escherichia coli and determination of incidence of gyrA mutations in clinical strains isolated from patients with complicated urinary tract infections. $J$ Clin Microbiol, 35(9), 2315-2319.

Ruiz, J. (2003). Mechanisms of resistance to quinolones: target alterations, decreased accumulation and DNA gyrase protection. J Antimicrob Chemother, 51(5), 11091117. doi: $10.1093 / \mathrm{jac} / \mathrm{dkg} 222$

Schaeffer, A. J. (2002). The expanding role of fluoroquinolones. Am J Med, $113 \mathrm{Suppl}$ $1 A, 45 \mathrm{~s}-54 \mathrm{~s}$.

Schito, G. C., Naber, K. G., Botto, H., Palou, J., Mazzei, T., Gualco, L., and Marchese, A. (2009). The ARESC study: an international survey on the antimicrobial resistance of pathogens involved in uncomplicated urinary tract infections. Int
J Antimicrob Agents, 34(5), 407-413. doi: 10.1016/j.ijantimicag.2009.04.012

Sotto, A., De Boever, C. M., Fabbro-Peray, P., Gouby, A., Sirot, D., and Jourdan, J. (2001). Risk factors for antibioticresistant Escherichia coli isolated from hospitalized patients with urinary tract infections: a prospective study. J Clin Microbiol, 39(2), 438-444. doi: 10.1128/jcm.39.2.438-444.2001

Tandogdu, Z., Cek, M., Wagenlehner, F., Naber, K., Tenke, P., van Ostrum, E., and Johansen, T. B. (2014). Resistance patterns of nosocomial urinary tract infections in urology departments: 8-year results of the global prevalence of infections in urology study. World J Urol, 32(3), 791-801. doi: 10.1007/s00345-0131154-8

Wayne, PA. (2007). Clinical and laboratory standards institute. Performance standards for antimicrobial susceptibility testing, 17.

Zhanel, G. G., Karlowsky, J. A., Harding, G. K., Carrie, A., Mazzulli, T., Low, D. E., and Hoban, D. J. (2000). A Canadian national surveillance study of urinary tract isolates from outpatients: comparison of the activities of trimethoprim-sulfamethoxazole, ampicillin, mecillinam, nitrofurantoin, and ciprofloxacin. The Canadian Urinary Isolate Study Group. Antimicrob Agents Chemother, 44(4), 1089-1092.

\section{How to cite this article:}

Rasha H. El-Mahdy, Mohammed A. Saleh and Aalaa Aboelnour. 2017. GyrA Mutations in Nosocomial Ciprofloxacin-Resistant Escherichia coli Isolates Associated with Urinary Tract Infections. Int.J.Curr.Microbiol.App.Sci. 6(2): 1902-1907. doi: http://dx.doi.org/10.20546/ijcmas.2017.602.215 